\title{
Company financial performance improvement through financial literacy and intellectual capital perspective
}

\author{
Moch. Kalam Mollah ${ }^{1}$, Suhartini ${ }^{2}$, Gatot Basuki Hari Mukti ${ }^{2}$ and Fatkhu Nasrudin \\ Khamimi $^{3}$ \\ ${ }^{1}$ Lecturer, Department of Industrial Engineering, Institut Teknologi Adhi Tama Surabaya, Indonesia \\ ${ }^{2}$ Lecturer, Department of Civil Engineering, Institut Teknologi Adhi Tama Surabaya, Indonesia \\ ${ }^{3}$ Undergraduate Student, Department of Industrial Engineering, Institut Teknologi Adhi Tama Surabaya, \\ Indonesia \\ Fatkhunk6@gmail.com
}

\begin{abstract}
CV. Sarindofood is one of the companies engaged in manufacturing snacks, one of which is a type of Tost and Stick products made from raw materials for industrial corn. CV. Sarindofood uses considerable capital resources, so it needs analysis, especially in the financial sector. This study aims to determine the effect of intellectual capital on corporate financial performance, financial literacy as an understanding of finance. The independent variables used in this study are human capital, structural capital, value-added capital employed, intellectual capital (VAIC). In contrast, the dependent variables include the performance of ROA, ROI, and ROE. The data in this study are the company's financial statement data CV. Sarindofood consists of a balance sheet report and cash flow for five years from 2019 to 2018. The method used in this study uses Multiple Linear Regression, VAIC, and partial ttest, and a simultaneous F-test is used as analysis tools to see each variable's effect. The results of this study indicate that Capital Employee partially has a significant impact on financial performance. Human capital partly has a significant and positive impact on financial performance. Structural capital partially has a significant and positive effect on financial performance. Whereas the value of the results simultaneously shows that the influence of Intellectual Capital on ROA has a significant effect of 60\%, Intellectual Capital on RO1 has a significant effect of 69\%, and Intellectual Capital on ROE has a significant effect of $55 \%$.
\end{abstract}

Keywords: financial, literacy, intellectual, capital, ROA, ROI, ROE

\section{Introduction}

In the competitive world of business, the current era of globalization is causing changes and international financial mobility to accelerate while affecting life in all aspects of finance and business ventures. The business world has experienced a lot of progress and rapid development, causing competition between companies in the industrial world is increasing [1]. Global and keen competition can narrow the profits of the company. In response to this, there is a need for information about company finances in making decisions in a timely, clear, and accurate manner [2].

The company prepares financial statements while describing the financial position clarity in all company activities, as well as the assets used and the profits obtained $[3,4]$. In this case, the company is intended to improve the company's financial performance. Financial statement analysis is a process of consideration that can help evaluate the condition, financial position, and also the results of the company's operations in the present and even in the past [5]. Through this analysis, the management knows a view of financial strength performance held at the same time can be used as decision making by company management, so it can be categorized as an evaluation in improving the company's financial performance by looking at 
financial literacy in corporate finance [6]. Corporate financial literacy in paying attention to capital costs so that they can make an investment decision [7,8].

$\mathrm{CV}$. Sarindofood is a manufacturing company engaged in snack food products, explicitly producing cornbased foods. There are several types of products produced, both Stick and Tost products, each year provides 6,000,000 packs that include some of the product variants, all of these products are $100 \%$ only for regional markets including Java, Kalimantan, and Sumatra. CV. Sarindofood, in the tight competition between companies at this time, the profits earned by the company did not match the expectations of the organization. The increase in earnings from year to year is accompanied by a massive increase in debt.

Based on the nominal value since 2019, there was an increase in net profit until 2019, but the nominal debt figure continues to increase even greater than the value of net income every year from the period 2019 to 2019. This suggests a problem arises from a lack of efficiency in managing company resources. For this reason, companies need to take new strategic steps to analyze all available resources to increase competitiveness in managing their resources so that they are more effective, efficient, and well-targeted according to organizational goals. Based on this problem, an assessment of the level of performance of the company's financial resources is carried out by perspective of financial literacy and knowledge of intellectual capital so that the company can minimize excess expenditure related to resources and optimize its use in the company.

In business financial management to improve financial performance, there are several quantitative methods of financial performance including the calculation of multiple linear regression, ROI (Return on Investment), ROE (Return on Equity) and ROA (Return on Asset) [9]. Some of the methods above can be used as a quantitative calculation that can balance the results of investment capital. It is also done by calculating intellectual capital through the Value Added Intellectual Coefficient (VAIC) method as well as knowing the company's financial performance improvement $[10,11]$. Furthermore, to combine the two using different test methods, namely the t-test and F-test.

This study aims to determine the effect of intellectual capital on corporate financial performance, financial literacy as an understanding of finance. So by knowing this relationship, the company has important information in determining strategic policies in financial management effectively and efficiently

\subsection{Literature Review ROA (Return on Asset)}

Return On Assets can measure a company's organizational ability in terms of generating profits by using the overall total assets of the company's assets after adjusting the costs to fund these assets is a variance in the calculation of ROA [12].

\section{ROI (Return on Investment)}

Stating ROI explanation is one of a form of profitability ratios used to measure a company's ability to cover the entire capital of funds that have been invested in assets as a financial performance of the company in order to produce certainty of profit [13].

\section{ROE (Return on Equity)}

Providing an understanding of ROE (Return On Equity) is part of the main tool used by investors to provide an assessment of the feasibility of shares [14]. Generally ROE is obtained from a profit sharing with equity in the last one year period. 


\section{Financial Literacy}

Stated financial literacy is the ability of an individual to absorb and process an economic information used in making decisions of financial accumulation and financial planning as well as debt as well as pensions [15]. Financial literacy can also be defined ability in decision making as well as effective considerations in the management of financial use [16].

\section{Intellectual Capital (IC)}

Intellectual Capital introduced by Pulic (1998) in its calculations is required to calculate the added value of the company [17]. Value added or Value Added (VA), i.e. calculating the entire company's revenue or income (Output) minus sales expenses, operating expenses and other expenses excluding salary expenses and employee expenses (Input) $[18,19]$. This method is to measure how and how efficient intellectual capital and employed capital are in creating value based on the relationship of three main components, namely (1) Human capital, (2) Capital employed, (3) Structural capital. Employee expenses in this study use the total salary and employee expenses listed in the financial statements[20].

\section{Method}

In the first stage, this will discuss the background of the problem from the research conducted, then the formulation of the problem that becomes the research material, determine the objectives of the study, determine the limits and assumptions used in the research and the benefits to be gained from the results of the research conducted. The following are each of the stages at the problem identification stage:

1. Identify the problem

At this stage explains that the initial stage of mastery of the problem in which a particular object in certain situations we can recognize as a problem. and identify problems that will be investigated, namely dealing with finances that are not as expected.

2. Formulation of the problem

This section explains the problems that will be discussed and resolved. The formulation of the problem will be directly related to the determination of objectives in this study.

Based on the theoretical basis and the results of previous studies and the problems raised, the theoretical framework in the model in the following Figure 1:
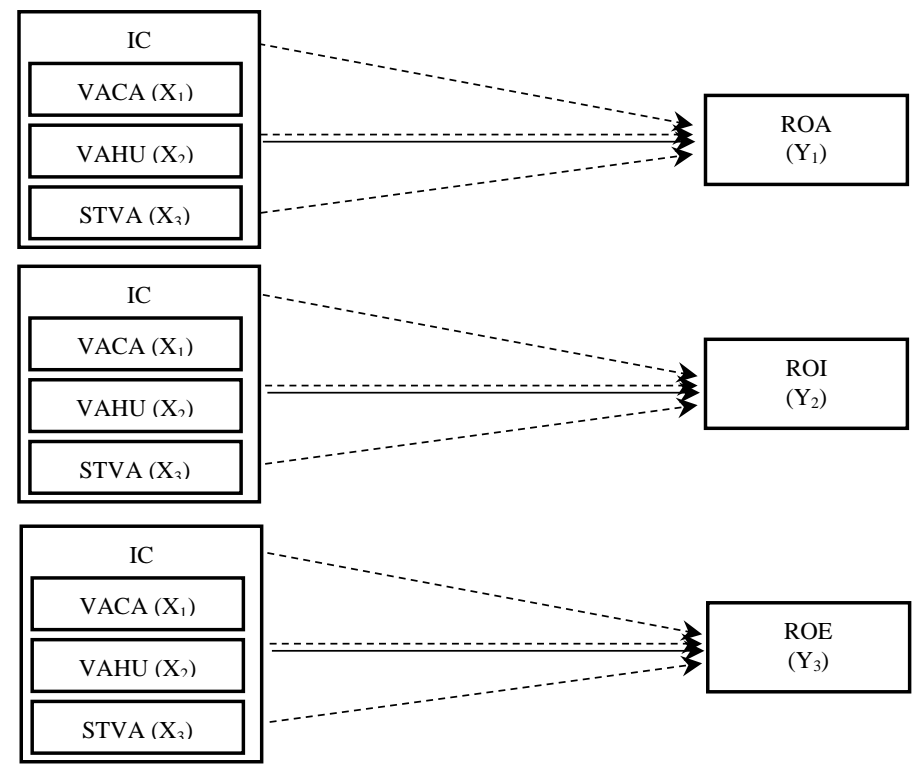

Figure 1. Model of the Research Framework 
Where:

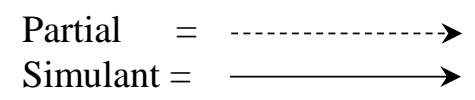

3. Determination of research objectives

This section explains the results of the research objectives to be achieved. The purpose will be directly related to the formulation of this problem. 4. Literature and field studies Literature study is a way to solve the problem under study by tracing the sources of writing that was previously made. Studying methods and theories that have a relationship with solutions that can be used in solving problems in a formula [20]. This field study was conducted by taking capital investment data and corporate financial reporting on the CV. Sarindofood.

4. Literature and field studies

Literature study is a way to solve the problem under study by tracing the sources of writing that was previously made. Studying methods and theories that have a relationship with solutions that can be used in solving problems in a formula. This field study was conducted by taking capital investment data and corporate financial reporting on the CV. Sarindofood.

\section{Results and Discussion}

In the next stage, the writer collects data to solve the problem. The data collected is as follows:

1. Data on the company's financial statements taken for five years, namely from 2019 to 2018. It is known from the data that there was an increase in profits from the year 2019 to the year 2018, but the increase in profits was accompanied by an increase in debt that was getting bigger. There is no balance between increasing profits with a much greater increase in debt.

2. Data on corporate investment reports in the period 2019 to 2018. Secondary investment report data to determine the capital used by the company in carrying out the company's survival.

3. Data income statement in the period 2019 to 2018. Data income statement is used to find out what the value of corporate profits in the CV. Sarindofood from 2019 to 2018.

4. Typical flow data from 2019 to 2018 . Typical company flow statement data is used to determine the financial flows that include financial flow activities.

5. The data above has been analyzed with quantitative calculations and processed in the order of the method.

\subsection{Validity Test}

Furthermore, the validity test and reliability test of the measuring instruments used in this study were tested.

Table 1. Validity Test Results

\begin{tabular}{|c|c|c|c|}
\hline Year Data & $\begin{array}{c}\text { Pearson Correlate } \\
\text { Value } \mathrm{df}=12, \alpha=0,05\end{array}$ & Value & Description \\
\hline VACA 2019 $\left(\mathrm{X}_{1.1}\right)$ & 0.5324 & 0.662 & Valid \\
VACA 2015 $\left(\mathrm{X}_{1.2}\right)$ & 0.5324 & 0.626 & Valid \\
VACA 2016 $\left(\mathrm{X}_{1.3}\right)$ & 0.5324 & 0.587 & Valid \\
VACA 2017 $\left(\mathrm{X}_{1.4}\right)$ & 0.5324 & 0.726 & Valid \\
VACA 2018 $\left(\mathrm{X}_{1.5}\right)$ & 0.5324 & 0.712 & Valid \\
VAHU 2019 $\left(\mathrm{X}_{2.1}\right)$ & 0.5324 & 0.769 & Valid \\
VAHU 2015 ( $\left.\mathrm{X}_{2.2}\right)$ & 0.5324 & 0.695 & Valid \\
VAHU 2016 $\left(\mathrm{X}_{2.3}\right)$ & 0.5324 & 0.570 & Valid \\
& & & \\
\hline
\end{tabular}


Table 1 Validity Test Results (cont)

\begin{tabular}{|cc|c|c|c|}
\hline Year Data & $\begin{array}{c}\text { Pearson Correlate } \\
\text { Value df= } 12, \alpha= \\
0,05\end{array}$ & Value & Description \\
\hline VAHU 2017 $\left(\mathrm{X}_{2.4}\right)$ & 0.5324 & 0.687 & Valid \\
VAHU 2018 $\left(\mathrm{X}_{2.5}\right)$ & 0.5324 & 0.698 & Valid \\
STVA & $2019\left(\mathrm{X}_{3.1}\right)$ & 0.5324 & 0.617 & Valid \\
STVA & $2015\left(\mathrm{X}_{3.2}\right)$ & 0.5324 & 0.654 & Valid \\
STVA & $2016\left(\mathrm{X}_{3.3}\right)$ & 0.5324 & 0.596 & Valid \\
STVA & $2017\left(\mathrm{X}_{3.4}\right)$ & 0.5324 & 0.751 & Valid \\
STVA & $2018\left(\mathrm{X}_{3.5}\right)$ & 0.5324 & 0.679 & Valid \\
IC & $2019\left(\mathrm{X}_{4.1}\right)$ & 0.5324 & 0.711 & Valid \\
IC & $2015\left(\mathrm{X}_{4.2}\right)$ & 0.5324 & 0.703 & Valid \\
IC & $2016\left(\mathrm{X}_{4.3}\right)$ & 0.5324 & 0.627 & Valid \\
IC & $2017\left(\mathrm{X}_{4.4}\right)$ & 0.5324 & 0.649 & Valid \\
IC & $2018\left(\mathrm{X}_{4.5}\right)$ & 0.5324 & 0.757 & Valid \\
ROA & $2019\left(\mathrm{Y}_{1.1}\right)$ & 0.5324 & 0.691 & Valid \\
ROA & $2015\left(\mathrm{Y}_{1.2}\right)$ & 0.5324 & 0.789 & Valid \\
ROA & $2016\left(\mathrm{Y}_{1.3}\right)$ & 0.5324 & 0.617 & Valid \\
ROA & $2017\left(\mathrm{Y}_{1.4}\right)$ & 0.5324 & 0.669 & Valid \\
ROA & $2018\left(\mathrm{Y}_{1.5}\right)$ & 0.5324 & 0.762 & Valid \\
ROE & $2019\left(\mathrm{Y}_{2.1}\right)$ & 0.5324 & 0.696 & Valid \\
ROE & $2015\left(\mathrm{Y}_{2.2}\right)$ & 0.5324 & 0.781 & Valid \\
ROE & $2016\left(\mathrm{Y}_{2.3}\right)$ & 0.5324 & 0.777 & Valid \\
ROE & $2017\left(\mathrm{Y}_{2.4}\right)$ & 0.5324 & 0.891 & Valid \\
ROE & $2018\left(\mathrm{Y}_{2.5}\right)$ & 0.5324 & 0.681 & Valid \\
ROI & $2019\left(\mathrm{Y}_{3.1}\right)$ & 0.5324 & 0.638 & Valid \\
ROI & $2015\left(\mathrm{Y}_{3.2}\right)$ & 0.5324 & 0.678 & Valid \\
ROI & $2016\left(\mathrm{Y}_{3.3}\right)$ & 0.5324 & 0.794 & Valid \\
ROI & $2017\left(\mathrm{Y}_{3.4}\right)$ & 0.5324 & 0.736 & Valid \\
ROI & $2018\left(\mathrm{Y}_{3.5}\right)$ & 0.5324 & 0.611 & Valid \\
\hline
\end{tabular}

Reliability Test Results Reliability tests are also carried out on both independent and dependent variables. The reliability test is based on the Cronbach Alpha value $(\alpha)$, if the Alpha Cronbach $(\alpha)$ value is greater than 0.60 then the research data is considered to be good enough and reliable to be used as input in the process of analyzing the data to test the research hypothesis (Maholtra, 1996).

Table 2. Results of Calculation of Reliability Tests

\begin{tabular}{|c|c|c|c|c|}
\hline No. & Variable & $\begin{array}{c}\text { Alpha Crombach } \\
\text { Value }\end{array}$ & $\begin{array}{c}\text { Reliability } \\
\text { Value }\end{array}$ & Description \\
\hline 1. & VACA & 0,6 & 0,768 & Reliable \\
\hline 2. & VAHU & 0,6 & 0.727 & Reliable \\
\hline 3. & STVA & 0,6 & 0,682 & Reliable \\
\hline 4. & IC & 0,6 & 0,683 & Reliable \\
\hline 5. & ROA & 0,6 & 0,698 & Reliable \\
\hline 6. & ROI & 0,6 & 0,688 & Reliable \\
\hline 7. & ROE & 0,6 & 0,665 & Reliable \\
\hline
\end{tabular}

\subsection{Multiple Linear Regression Analysis of ROA}

The following are the results of the recapitulation calculation of the results of the multiple linear regression analysis of ROA's financial performance. 
Table 3. Recapitulation of Results of Multiple Linear Regression Analysis of ROA

\begin{tabular}{|c|c|c|c|c|c|}
\hline No. & Variable & Regression Coefficient $(\mathrm{b})$ & $\mathrm{T}$ & $\mathrm{Sig}$ & $\mathrm{r}^{2}$ \\
\hline 1. & VACA Factor $\left(\mathrm{X}_{1}\right)$ & 0,051 & 4,373 & 0,11 & 0,600 \\
\hline 2. & VAHU Factor $\left(\mathrm{X}_{2}\right)$ & 0,307 & 2,237 & 0,29 & 0,600 \\
\hline 3. & STVA Factor $\left(\mathrm{X}_{3}\right)$ & 0,111 & 1,855 & 0,36 & 0,600 \\
\hline $\mathrm{R}$ & & F Change & $=3,062$ \\
$\mathrm{R}^{2}$ & & Sig. F & $=0,035$ \\
Constanta & $=0,775$ & Durbin Watson & $=2,362$ \\
Standard Error $=0,600$ & & & \\
\hline
\end{tabular}

Analysis of Multiple Linear Regression of ROI The following are the results of the recapitulation calculation of the results of the multiple linear regression analysis of ROI's financial performance.

Table 4. Recapitulation of Results of Multiple Linear Regression Analysis of ROI

\begin{tabular}{|c|c|c|c|c|c|}
\hline No. & Variable & Regression Coefficient (b) & $\mathrm{T}$ & Sig & $r^{2}$ \\
\hline 1. & VACA Factor $\left(\mathrm{X}_{1}\right)$ & 0,106 & 1,921 & 0,036 & 0,690 \\
\hline 2. & VAHU Factor $\left(\mathrm{X}_{2}\right)$ & 0,569 & 4,950 & 0,041 & 0,690 \\
\hline 3. & STVA Factor $\left(\mathrm{X}_{3}\right)$ & 0,037 & 2,344 & 0,032 & 0,690 \\
\hline $\begin{array}{l}\mathrm{R} \\
\mathrm{R}^{2} \\
\text { Const } \\
\text { Stand }\end{array}$ & $\begin{array}{l}=0,831 \\
=0,690 \\
=-4,992 \\
=0,169\end{array}$ & & \multicolumn{3}{|c|}{$\begin{array}{ll}\text { F Change } & =12,366 \\
\text { Sig. F } & =0,000 \\
\text { Durbin Watson } & =1,616\end{array}$} \\
\hline
\end{tabular}

Analysis of Multiple Linear Regression of ROE The following are the results of the recapitulation calculation of the results of the multiple linear regression analysis of ROE's financial performance.

Table 5. Recapitulation of Results of Multiple Linear Regression Analysis of ROE

\begin{tabular}{|c|c|c|c|c|c|}
\hline No. & Variable & Regression Coefficient (b) & $\mathrm{T}$ & Sig & $\mathrm{r}^{2}$ \\
\hline 1. & VACA Factor $\left(\mathrm{X}_{1}\right)$ & 0,075 & 2,533 & 0,035 & 0,690 \\
\hline 2. & VAHU Factor $\left(\mathrm{X}_{2}\right)$ & 0,319 & 2,293 & 0,026 & 0,690 \\
\hline 3. & STVA Factor $\left(\mathrm{X}_{3}\right)$ & 0,063 & 4,481 & 0,033 & 0,690 \\
\hline \multicolumn{2}{|c|}{$\begin{array}{lcc}\mathrm{R} & =0,745 \\
\mathrm{R}^{2} & =0,555 \\
\text { Constanta } & =3,102 \\
\text { Standard Error } & =0,255\end{array}$} & & \multicolumn{3}{|c|}{$\begin{array}{ll}\text { F Change } & =2,829 \\
\text { Sig. F } & =0,036 \\
\text { Durbin Watson } & =1,333\end{array}$} \\
\hline
\end{tabular}

Then a partial t-test is performed to determine the effect of each independent variable partially on the dependent variable. The analysis steps in testing the hypothesis of the regression coefficient are as follows:

1. Decision making, the value of $t$ is calculated against $t$ tables in ROA 
Table 6. Comparison of the $t$ Value with $t$ Table in ROA

\begin{tabular}{|c|c|c|}
\hline Variable & $\mathrm{t}$ Tabel & t Calculate \\
\hline VACA $\left(\mathrm{X}_{1}\right)$ & 1,671 & 4,372 \\
VAHU $\left(\mathrm{X}_{2}\right)$ & 1,671 & 2,237 \\
STVA $\left(\mathrm{X}_{3}\right)$ & 1,671 & 1,855 \\
\hline
\end{tabular}

Based on the comparison of the value of $t$ arithmetic with $t$ table where $t$ arithmetic is located above or outside the $t$ table interval, it can be concluded that the factor of the Intellectual Capital (IC) variable consisting of the factor $\mathrm{X}_{1}$ value added capital employed (VACA), the factor $\mathrm{X}_{2}$ value added human capital (VAHU), and $\mathrm{X}_{3}$ structural capital value added (STVA) factors influence each variable partially significantly on return on assets (ROA) in the company CV. Sarindofood (reject $\mathrm{H}_{0}$ and accept $\mathrm{H}_{1}$ ), so that the second hypothesis is proven true.

2. Decision making of the $t$ value calculated against $t$ tables in ROI

Table 7. Comparison of $t$ Calculated Values with $t$ Tables on ROI

\begin{tabular}{|c|c|c|}
\hline Variable & $\mathrm{t}$ Tabel & t Calculate \\
\hline VACA $\left(\mathrm{X}_{1}\right)$ & 1,671 & 1,921 \\
VAHU $\left(\mathrm{X}_{2}\right)$ & 1,671 & 4,950 \\
STVA $\left(\mathrm{X}_{3}\right)$ & 1,671 & 2,344 \\
\hline
\end{tabular}

Based on the comparison of the value of $t$ arithmetic with $t$ table where $t$ arithmetic is located above or outside the $t$ table interval, it can be concluded that the factors of the Intellectual Capital (IC) variable consisting of factors $X_{1}$ value added capital employed (VACA), factor $X_{2}$ value added human capital (VAHU), and $\mathrm{X}_{3}$ structural capital value added factor (STVA) have an effect on each variable partially significantly on return on investment (ROI) at CV. Sarindofood (reject $\mathrm{H}_{0}$ and accept $\mathrm{H}_{1}$ ), so that the second hypothesis is proven true.

3. Decision making values of $t$ count against $t$ table in ROI

Table 8. Comparison of the $t$ Value with $t$ Table in ROE

\begin{tabular}{|c|c|c|}
\hline Variable & $\mathrm{t}$ Tabel & t Calculate \\
\hline VACA $\left(\mathrm{X}_{1}\right)$ & 1,671 & 2,533 \\
VAHU $\left(\mathrm{X}_{2}\right)$ & 1,671 & 2,293 \\
STVA $\left(\mathrm{X}_{3}\right)$ & 1,671 & 4,481 \\
\hline
\end{tabular}

Based on the comparison of the value of $t$ arithmetic with $t$ table where $t$ arithmetic is located above or outside the $t$ table interval, it can be concluded that the factors of Intellectual Capital (IC) variables consisting of factors $\mathrm{X}_{1}$ (VACA), factor $\mathrm{X}_{2}$ (VAHU) ), and $\mathrm{X}_{3}$ factors (STVA) influence each variable partially significantly on return on equity (ROE) in the company $\mathrm{CV}$. Sarindofood (reject $\mathrm{H}_{0}$ and accept $\mathrm{H}_{1}$ ), so the hypothesis is proven true.

\subsection{F Test}

Next to test the influence of independent variables together using the F-test statistical techniques. Decision Making The simultance relationship between $\mathrm{F}$ tables and $\mathrm{F}$ arithmetic based on calculations can produce a determination whether the relationship is influential or not. The following are the results of calculating the simultaneous effect of several factors. 
Table 9. Relationships of Simultaneous Effects of Factors.

\begin{tabular}{|l|c|c|c|}
\hline \multicolumn{1}{|c|}{ Simultaneous } & $\mathrm{df}=3 ; \alpha=0,05$ & F Calculate & Conclusion \\
\hline VACA, VAHU, STVA => ROA & 2,77 & 3,06 & Simultaneous influential relationship \\
\hline VACA, VAHU, STVA => ROI & 2,77 & 12,36 & Simultaneous influential relationship \\
\hline VACA, VAHU, STVA => ROE & 2,77 & 2,82 & Simultaneous influential relationship \\
\hline
\end{tabular}

\section{Conclusion}

Based on the results of the value of Intellectual Capital in the CV. Sarindofood in 2019 amounted to 7.07 obtained from processing the results of the VACA value of 1.29, VAHU of 4.99, and STVA of 0.79. Furthermore, the Intellectual Capital ratio in 2015 of 7.36 was obtained from processing the value of the results from VACA of 1.25, VAHU of 5.30, and STVA of 0.81 and the value of Intellectual Capital in 2016 of 7.96 was obtained from processing VACA value of 1.17, VAHU of 5.96, and STVA of 0.83. In 2017 Intellectual Capital value of 9.14 was obtained from the acquisition of VACA of 1.34, VAHU of 6.95, and STVA of 0.85. In 2018 an Intellectual Capital value of 8.83 was obtained from VACA processing of 1.42, VAHU of 6.57, and STVA of 0.84. From the results obtained, the relationship of each variable VACA (X1) to ROI, VAHU (X2) to ROI, and STVA (X3) to ROA partially has a significant effect on ROA performance, while the effect of increasing simultaneously on Y variables the value of $\mathrm{R}$ results is 0.775 and this proves that in this study the influence of Intellectual Capital on ROA is very strong because it is above the reference coefficient of correlation 0.50 and the effect value is R2 0.600 or $60 \%$ effect.

From the results obtained, the relationship of the influence of each variable VACA (X1) on ROI, VAHU (X2) on ROI, and STVA (X3) on ROI partially has a significant and positive effect on ROI performance, to influence the simultaneous increase in ROI the variable ROI (Y) obtained an R value of 0.831 and this proves that in this study the relationship of Intellectual Capital to ROI had a very strong effect seen from the magnitude of the $\mathrm{R}$ value above the reference correlation coefficient 0.50 and the effect was R2 0.690 or an effect of $69 \%$. 4. Based on the results obtained, the relationship of the effect of each variable VACA (X1) on ROI, VAHU (X2) on ROI, and STVA (X3) on ROE partially has a significant and positive effect on ROE performance, while the effect of increasing simultaneously on the ROE variable creates an $\mathrm{R}$ value of 0.745 and this is evidenced by the very strong influence of the intellectual capital relationship to ROE of 55\% with an R2 of 0.555. 5.

\section{References}

[1] M. Delgado. 2011. The Role of Intellectual Capital Assets on the Radicalness of Innovation : Direct and Moderating Effects. UAM-Accent. Work. Pap., pp. 1-27.

[2] I. J. dos S. Felipe, H. B. Ceribeli, and T. Q. Lana. 2017. Investigating the level of financial literacy of university students. RACE - Rev. Adm. Contab. e Econ., vol. 16, no. 3, pp. 845-866.

[3] R. Prabowo, M. L. Singgih, P. D. Karningsih, and E. Widodo. 2020. New product development from inactive problem perspective in indonesian SMEs to open innovation. J. Open Innov. Technol. Mark. Complex., vol. 6, no. 1.

[4] B. Bayaraa. 2017. Financial Performance Determinants of Organizations: The Case of Mongolian Companies. J. Compet., vol. 9, no. 3, pp. 22-33.

[5] B. Swiecka, E. Yeşildağ, E. Özen, and S. Grima. 2020. Financial literacy: The case of Poland Sustain., vol. 12, no. 2, pp. 1-17.

[6] T. Chiarello, C. Pletsch, A. Silva, and T. Silva. 2019. Financial Performance, Intangible Assets and 
Value Creation of Brazilian and Chilian Companies of Information Technology. Rev. Galega Econ., vol. 23 , no. 4, pp. 73-88.

[7] L. M. Crane. 2003. Measuring Financial Performance: A Critical Key to Managing Risk.

[8] S. Suhartini, E. Yuliawati, N. Rahmawati, and D. A. H. Syahputra. 2018. Implementation of Lean Services in Hospitals To Improve The Efficiency of Patient Services in The Organization of Health Social Security (BPJS). IPTEK J. Proc. Ser., vol. 0, no. 6, pp. 64-71.

[9] A. C. Valentin. 2011. Determinants of corporate financial performance, pp. 1-17.

[10] F. B. Kaya, G. G. Sahin, and P. Gurson. 2010. Intellectual capital in organizations. Probl. Perspect. Manag., vol. 8, no. 1, pp. 153-160.

[11] M. Y. Cheng, J. Y. Lin, T. Y. Hsiao, and T. W. Lin. 2010. Invested resource, competitive intellectual capital, and corporate performance. J. Intellect. Cap., vol. 11, no. 4, pp. 433-450.

[12] A. Lusardi and O. S. Mitchell. 2019. The economic importance of financial literacy: Theory and evidence. J. Econ. Lit., vol. 52, no. 1, pp. 5-44.

[13] A. I. Ferreira and L. F. Martinez. 2011. Intellectual capital: perceptions of productivity a and investment. Rev. Adm. Contemp., vol. 15, no. 2, pp. 249-260.

[14] R. Myšková and P. Hájek. 2017. Comprehensive assessment of firm financial performance using financial ratios and linguistic analysis of annual reports. J. Int. Stud., vol. 10, no. 4, pp. 96-108.

[15] P.-C. Michaud. 2017. The value of financial literacy and financial education for workers. IZA World Labor, no. November, pp. 1-11.

[16] I. E. Karaa and T. D. Kuğu. 2016. Determining advanced and basic financial literacy relations and overconfidence, and informative social media association of university students in Turkey. Kuram ve Uygulamada Egit. Bilim., vol. 16, no. 6, pp. 1865-1891.

[17] L. Nerdrum and T. Erikson. 2001. Intellectual capital: A human capital perspective. J. Intellect. Cap., vol. 2, no. 2, pp. 127-135.

[18] P. Åhblom. 2017. The Financial Performance: A study of how financial numbers become meaningful.

[19] K. Marcin. 2013. Intellectual Capital as a Key Factor of Socio-economic Development of Regions and Countries. Procedia Econ. Financ., vol. 6, no. 13, pp. 288-295.

[20] Suhartini and Hastawati. C. S. 2020. Selecting the synthetic leather and outsole supplier for shoe production in small medium enterprise. AIP Conference Proceeding., vo.2217. April 2020. 